\title{
Recruitment of Audouin's gull to the Ebro Delta colony at metapopulation level in the western Mediterranean
}

\author{
Daniel Oro ${ }^{1,2, *}$, Roger Pradel ${ }^{1}$ \\ ${ }^{1}$ CEFE, CNRS, 1919 route de Mende, F-34293 Montpellier cedex 5, France \\ ${ }^{2}$ Dept. Biologia Animal, Vertebrats, Universitat de Barcelona, Diagonal 645, E-08028 Barcelona, Spain
}

\begin{abstract}
Few studies have been carried out on movements among local populations of long-lived birds due to the difficulty of marking and following individuals in different populations within a metapopulation for the long term. An extensive long-term ringing programme carried out in most of the local breeding populations (i.e. colonies) within the western Mediterranean metapopulation of Audouin's gull allowed us to assess the probability of a gull being recruited into the Ebro Delta colony according to the colony of birth. The studied metapopulation includes $93 \%$ of total world population of breeding pairs. Resights of 1302 ringed breeders during 1 breeding season at the Ebro Delta were used to model the probability of recruiting as a function of distance from the natal colony. A negative binomial distribution accounting for overdispersion was fitted in the framework of generalized linear models. Distance explained $97 \%$ of the difference among colonies which themselves accounted for $67 \%$ of the total deviance. Recruitment probability decreased exponentially with distance from the Ebro Delta colony, despite the high movement capabilities of the species during the breeding and non-breeding seasons. However, dispersal was recorded even from the most distant colony at $655 \mathrm{~km}$ from the Ebro Delta, although at a very low rate. Results agree with the prediction of several theoretical models of animal movement that distance is one of the most important determinants of dispersal and colonization rates within metapopulations.
\end{abstract}

KEY WORDS: Audouin's gull $\cdot$ Recruitment $\cdot$ Metapopulation - Distance $\cdot$ Colony growth $\cdot$ Population dynamics

\section{INTRODUCTION}

The study of population dynamics at the metapopulation level has received much attention in the last few years (e.g. Hanski \& Gilpin 1997 and references therein). A metapopulation is an assemblage of discrete local populations (called simply populations hereafter) connected by migration and exchanging a negligible number of individuals with the outside. In fact, the transfer of individuals across space is a key

\footnotetext{
"Present address: Applied Ornithology Unit, Division of Environmental and Evolutionary Biology, Graham Kerr Building, Glasgow University, Glasgow G12 8QQ, United Kingdom. E-mail: doro001@udcf.gla.ac.uk
}

process in metapopulation dynamics. The transfer of individuals (or dispersal when it occurs among breeding populations) may be a process of emigration (i.e. the individual leaves its home site) or immigration (i.e. the individual occupies a site other than its natal site) (e.g. Ims \& Yoccoz 1997). In this context dispersal implies recruitment, a process that influences local population dynamics. Recruitment can be defined as the entry of individuals into the breeding compartment of a population. Recruitment includes both immigrant (i.e. dispersal, both natal and breeding) and nonemigrant individuals (Clobert et al. 1993). Breeding individuals have the option to recruit to their natal site (i.e. with no natal dispersal) or to move to another site (i.e. natal dispersal), or even to disperse after breeding 


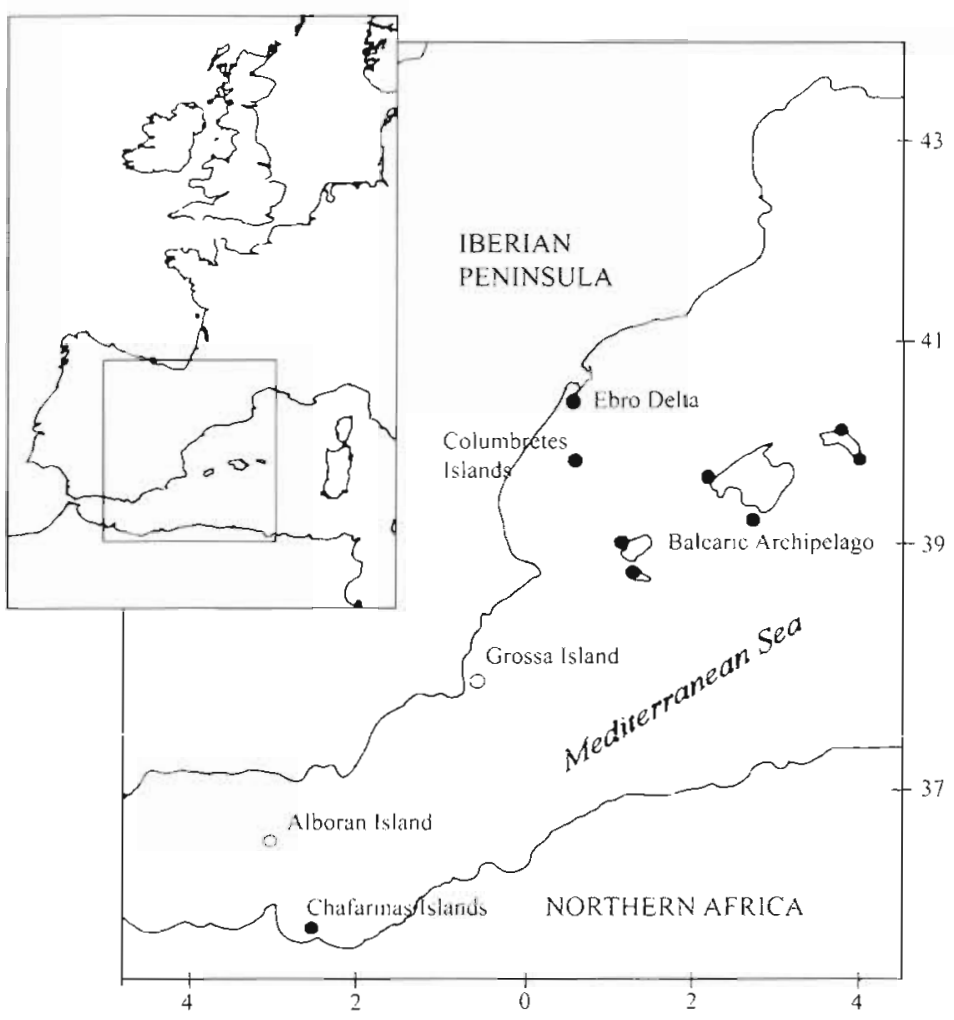

Fig. 1. Location of the Audouin's gull colonies in the western Mediterranean where chicks have been individually ringed since 1988. The colony of Isla Grossa, established in 1989, and that of Alborán Island, recolonised in 1988, are also shown (O), although only irregularly have chicks been ringed there

at a particular site (i.e. breeding dispersal). Finally, when individuals disperse, they can move to an established colony or they can colonize a new breeding site.

Metapopulation models have been increasingly used especially in conservation and population biology. Modeling the dynamics of threatened species at the metapopulation level is essential due to the current increase of fragmentation of animal populations as the result of human activities (Smith \& Peacock 1990). In population biology, metapopulation models have introduced the role of the spatial structure of populations to the study of their dynamics and demographic processes, such as recruitment. Distance between populations has been identified as one of the most important factors in several models of animal movement within metapopulations. For instance, distance between the mainland and an island is believed to be an important determinant of dispersal and colonization rates (MacArthur \& Wilson 1967). Similarly, migration rates are hypothesized to decrease with distance in both discrete, stepping-stone models and continuous, population-genetic models (see review in Hanski \& Gilpin 1997). However, empirical evidence to support metapopulation theory is not easy to obtain, and several authors have pointed out the great difficulties associated with obtaining data on the transfer process in metapopulations, especially in long-lived birds with large geographical ranges (Johnson \& Gaines 1990, Cooke \& Francis 1993, Pradel 1996, Ims \& Yoccoz 1997). A long-term ringing programme carried out at most of the colonies of Audouin's gull Larus audouinii in the western Mediterranean metapopulation allowed us to assess the effect of distance on recruitment from several colonies to the Ebro Delta colony, the largest in the world (Oro 1998, Oro et al. 1999; Table 1, Fig. 1). In our study, recruitment means the accession of mature gulls to the breeding colony at the Ebro Delta, independently of whether or not these gulls were breeding in the years before. Little is known about the movement capacities of the Laridae, but in general they are less mobile than other seabirds such as the procellariforms (del Hoyo et al. 1996). However, Audouin's gulls may move long distances during both breeding and non-breeding seasons. During breeding, gulls with chicks may move further than $150 \mathrm{~km}$ from the colony looking for food (Arcos \& Oro 1996, Oro 1998, Oro unpubl. data). After breeding, most of the gulls leave the colonies and migrate to wintering areas more than $3500 \mathrm{~km}$ away from their breeding sites (Oro \& Martínez-Vilalta 1994, Jiménez \& Carda 1997, Oro 1998). Thus, it would be expected that distance between colonies within the western Mediterranean metapopulation of Audouin's gulls (with a maximum distance between colonies of $655 \mathrm{~km}$, see below) would not constitute a barrier against dispersal of individuals.

Table 1. Colony sizes (as number of breeding pairs) at the western Mediterranean Audouin's gull metapopulation in 1997; numbers at the colony of Grossa Island and Alboran Island are also shown, although these colonies are not included in the analysis (see text and also Fig. 1). Total world population in 1997 is estimated at 18500 breeding pairs (Oro 1998)

\begin{tabular}{|lrcc|}
\hline Colony & Size & $\begin{array}{c}\% \text { meta- } \\
\text { population }\end{array}$ & $\begin{array}{c}\text { \%world } \\
\text { population }\end{array}$ \\
\hline Ebro Delta & 11700 & 68.3 & 63.2 \\
Chafarinas Islands & 2700 & 15.8 & 14.6 \\
Balearic Archipelago & 1650 & 9.6 & 8.9 \\
Columbretes Islands & 525 & 3.1 & 2.8 \\
Grossa Island & 450 & 2.6 & 2.4 \\
Alborán Island & 100 & 0.6 & 0.5 \\
Total & 17125 & 100 & 92.6 \\
\hline
\end{tabular}




\section{STUDY AREA AND METHODS}

Audouin's gull is an endemic breeding seabird found in the Mediterranean region, and it is considered threatened by extinction (Mace \& Collar 1994, Lambertini 1996). During the 1960s, the world population of the species was estimated at only 600 to 800 pairs, although since the establishment, in 1981, of a new colony in the Ebro Delta the total number of breeding pairs has dramatically increased (Oro 1998). At this colony, 36 pairs were established initially in 1981, and in 1997 more than 11700 pairs bred. Protection against human disturbances and predatory species has increased the size of most of the colonies in the region, especially in the western Mediterranean (Oro 1998 and references therein). At the metapopulation level populations in the western Mediterranean have always been the largest, probably due to the higher food availability in this part of the Mediterranean (Oro et al. 1996a). In this western Mediterranean metapopulation, $93 \%$ of the total world population of the species is concentrated (Oro 1998; see Table 1).

As part of a long-term study of the breeding biology and population dynamics of Audouin's gull, between 5 and $25 \%$ of the chicks have been individually marked each year since 1988 in several colonies in the western Mediterranean (Fig. 1). Chicks have been ringed at the end of their growth period, with plastic rings (with an individual alphanumeric code) on the leg. The alphanumeric code on the rings can be read using a telescope from a distance of up to $150 \mathrm{~m}$ (Oro et al. in press). Between 1988 and 1994, 10889 chicks were ringed in this metapopulation, including chicks from the colonies of the Ebro Delta, Columbretes Islands, Chafarinas Islands and most of the colonies in the population at the Balearic Archipelago (the 2 colonies located in Menorca, the colonies located at the Cabrera Archipelago and several colonies located in the Pitiusas Archipelago) (Table 2, Fig. 1). All data from the ringing carried out in the Balearic colonies were grouped due to the low number of chicks ringed at each colony each year. In the colonies of Grossa Island and Alborán Island ca 500 chicks were ringed in the last few years but only irregularly and these data were not included in the analysis. Minimum distances of the different colonies from the Ebro Delta colony are: $81 \mathrm{~km}$ for the Columbretes Islands, $252 \mathrm{~km}$ average for the colonies of the Balearic Archipelago and $655 \mathrm{~km}$ for the Chafarinas Islands. Natal and breeding dispersal could not be analyzed separately because of the low number of emigrants from other colonies to the Ebro Delta colony (see below).

Resightings were conducted in the Punta de la Banya colony (Ebro Delta Natural Park, $40^{\circ} 37^{\prime} \mathrm{N}, 00^{\circ}$ $35^{\prime}$ E), a sandy beach of 2500 ha with several dunes
Table 2. Number of chicks ringed at different Audouin's gull colonies in the western Mediterranean from 1988 to 1994 Resights of breeding birds at the Ebro Delta colony in 1997 are shown, for every colony of origin and cohort. Since resightings of ringed birds were performed in 1997, only the cohorts of mature breeding birds ringed up to 1994 are included. Ringings at the different colonies of the Balearic Archipelago are grouped

\begin{tabular}{|c|c|c|c|c|}
\hline Colony & Cohort & $\begin{array}{c}\text { No. } \\
\text { marked } \\
\text { as chicks }\end{array}$ & $\begin{array}{c}\text { No. } \\
\text { resighted } \\
\text { in } 1997\end{array}$ & $\begin{array}{l}\text { Proportion } \\
\text { resighted } \\
\text { in } 1997(\%)\end{array}$ \\
\hline Ebro Delta & 1994 & 657 & 501 & 76.26 \\
\hline Ebro Delta & 1993 & 842 & 335 & 39.79 \\
\hline Ebro Delta & 1992 & 769 & 269 & 34.98 \\
\hline Ebro Delta & 1991 & 389 & 97 & 24.94 \\
\hline Ebro Delta & 1990 & 361 & 33 & 9.14 \\
\hline Ebro Delta & 1989 & 557 & 2 & 0.36 \\
\hline Ebro Delta & 1988 & 1049 & 8 & 0.76 \\
\hline Total Ebro Delta & & 4624 & 1245 & \\
\hline Balearic Arch. & 1994 & 229 & 3 & 1.31 \\
\hline Balearic Arch. & 1993 & 213 & 2 & 0.94 \\
\hline Balearic Arch. & 1992 & 145 & 3 & 2.07 \\
\hline Balearic Arch. & 1991 & 216 & 11 & 5.09 \\
\hline Balearic Arch. & 1990 & 14 & 0 & 0.00 \\
\hline Balearic Arch. & 1989 & 62 & 0 & 0.00 \\
\hline Balearic Arch. & 1988 & 223 & 1 & 0.45 \\
\hline \multicolumn{2}{|c|}{ Total Balearic Arch. } & 1102 & 20 & \\
\hline Columbretes Is. & 1994 & 32 & 4 & 12.50 \\
\hline Columbretes Is. & 1993 & 1 & 0 & 0.00 \\
\hline Columbretes Is. & 1992 & 37 & 0 & 0.00 \\
\hline Columbretes Is. & 1990 & 104 & 0 & 0.00 \\
\hline Columbretes Is. & 1989 & 110 & 8 & 7.27 \\
\hline Columbretes Is. & 1988 & 208 & 24 & 11.54 \\
\hline \multicolumn{2}{|c|}{ Total Columbretes Is. } & 492 & 36 & \\
\hline Chafarinas Is. & 1994 & 728 & 0 & 0.00 \\
\hline Chafarinas Is. & 1993 & 783 & 0 & 0.00 \\
\hline Chafarinas ls. & 1992 & 1011 & 0 & 0.00 \\
\hline Chafarinas ls. & 1991 & 721 & 0 & 0.00 \\
\hline Chafarinas Is. & 1990 & 442 & 0 & 0.00 \\
\hline Chafarinas Is. & 1989 & 210 & 1 & 0.48 \\
\hline Chafarinas Is. & 1988 & 776 & 0 & 0.00 \\
\hline \multicolumn{2}{|c|}{ Total Chafarinas Is. } & 4671 & 1 & \\
\hline \multicolumn{2}{|l|}{ Total colonies } & 10889 & 1302 & \\
\hline
\end{tabular}

covered by psammophilous vegetation, where the gulls breed. More than 1000 ha are occupied by a complex of commercial salt pans, where Audouin's gull also breed in large numbers. The numbers of marked individuals resighted at the Ebro Delta colony, $R_{\mathrm{c}, \mathrm{h}, \mathrm{y}}$ can be classified by colony of origin (c), cohort of birth (h) and year of resighting (y). Obviously, the numbers resighted in different years are not independent as the same individuals may be resighted several times. Hence, repeating the analysis for different years would be pseudoreplication. To conduct our analysis we will, thus, focus on just 1 year, namely 1997. Although resightings have been extensively performed at this colony since 1992 (Oro et al. 1999), we chose 1997 since it was the year with the largest number of re- 
sightings with known individual breeding status. From March to July, we searched for ringed birds in all the sub-colonies in order to distribute the resighting effort throughout the whole colony. Birds were resighted within the sub-colonies, and only individuals seen breeding (with eggs or chicks) were considered. We retained 1302 resightings of breeding individuals, which we modelled (Table 2). At the Ebro Delta in 1997 for a given cohort (year of birth) and a given colony of origin, the number of individuals resighted was typically a binomial variable number of success out of a given number of trials) (see for instance Crawley 1993, p. 265), and, as the different cohorts can be tentatively considered as independent, the number of breeders resighted in 1997 may naturally be thought of as following independent binomial distributions (B):

$$
R_{\mathrm{c}, \mathrm{h}} \approx \mathrm{B}\left(\mathrm{N}_{\mathrm{c}, \mathrm{h}}, j r_{\mathrm{c}} s^{1997-\mathrm{c}-3} a_{1997-\mathrm{c}} \mathrm{p}\right)
$$

$N_{c, h}$ is the number of chicks of cohort h originally marked on colony c. $j$ is the survival to age 3 (age of first reproduction for Audouin's gulls). $r_{c}$ is the probability of a bird born on colony $\mathrm{c}$ and having survived to breed being recruited to the Ebro Delta colony. This parameter is exactly the probability of encountering an individual as a breeder at the Ebro Delta colony in 1997. A reasonable assumption is that breeding dispersal is rare in this metapopulation (for instance, the probability of breeding dispersal from other colonies to the Ebro Delta colony is lower than 0.02, Oro unpubl. results) so a breeder at the Ebro Delta colony in 1997 has almost certainly been there since it started to breed and will remain there as long as it breeds. $s$ is the adult survival (supposed constant for the species during the study period). $a_{1}$ is the breeding propensity at age $i$ (supposed to depend only on age) (e.g. Pradel et al. 1997). p is the capture or resighting probability at the Ebro Delta colony in 1997.

$\mathrm{N}_{c, h}, s, a_{i}$ and $\mathrm{p}$ are known quantities from the literature, whereas $r_{c}$ is the quantity of interest and $j$ is another unknown. $s=0.908$ (previous survival analysis, Oro et al. 1999). $a_{i}=0.84,0.90$ and 0.96 for 3,4 and 5 yr-olds respectively, and 1 afterwards (previous recruitment analysis, Oro \& Pradel in press). $\mathrm{p}=$ 0.658061 (previous survival analysis).

As an alternative to binomial distributions we may use Poisson distributions (P) which are almost equivalent with this kind of data:

$$
R_{c . h} \approx \mathrm{P}\left(\mathrm{N}_{\mathrm{c}, \mathrm{h}} j r_{\mathrm{c}} s^{\mathrm{y}-\mathrm{c}-3} \mathrm{a}_{\mathrm{y}-\mathrm{c}} \mathrm{p}\right)
$$

Indeed, Poisson models $P(N, p)$ are a good approximation to binomial models $B(N, p)$ when $N$ is large (which is the case for birds born at the Ebro Delta colony) or $p$ is small (birds from the other colonies) (Crawley 1993) (see number marked and proportion resighted in Table 2). Using Poisson models will thus make little difference
Given that we had the choice, we opted to use the Poisson distribution which has the following advantages. First, because the Poisson distribution takes the logarithm as its natural link function, the colony effect in Eq. (1) will appear as an additive term, $\log \left(r_{c}\right)$.

$$
\log \left[E\left(R_{\mathrm{c}, \mathrm{h}}\right)\right]=\mathrm{A}_{\mathrm{c}, \mathrm{h}}+\log (j)+\log \left(r_{\mathrm{c}}\right)
$$

where $A_{c, h}=\log \left(N_{c, h} S^{y-c-3} a_{y-c} p\right)$ is a known quantity, $\log (j)$ is a constant and $\log \left(I_{\mathrm{c}}\right)$ will vary with $c_{\text {, the nat }}$ colony. The colony effect can thus be modelled easily in the framework of generalized linear models (see for instance, Crawley 1993, Chapter 14). It will, for instance, be possible to replace the colony effect by a distance effect, thus modelling the probability of recruitment to the Ebro Delta colony as an exponentially decreasing function of distance from the natal. colony. Second, in case of overdispersion, which may arise if individuals do not move independently but in flocks, it will be possibie to resort to a relatively simple generalization of the Poisson distribution, the negative binomial distribution. The negative binomial distribution, like the Poisson distribution, takes the logarithm as its natural link function and can thus be fitted in the framework of generalized linear models with the same advantages.

All models were fitted with software GLIM (Aitkin et al. 1988): the error specification was Poisson or negative binomial; the link function was the logarithm; the known values $A_{c . h}$ were treated as an offset vector. $\log (j)$ entered the intercept and $\log \left(x_{c}\right)$ gave rise to a colony effect which could be substituted by effect of distance between colonies.

\section{RESULTS AND DISCUSSION}

The fit of the Poisson models is shown in Table 3: the colony effect accounts for $65 \%$ of the total deviance ([Dev null model - Dev colony model]/Dev null model), and distance measured in $\mathrm{km}$ explains $99.8 \%$ of the colony effect ([Dev distance model - Dev colony model]/Dev distance model). However, the Poisson distribution is not at all satisfactory and may lead to erroneous conclusions because there is a tremendous lack of fit: the residual deviance is 45 times its degrees of freedom for the colony or distance models when it

Table 3. Deviances and residual degrees of freedom of the Poisson models

\begin{tabular}{|lcc|}
\hline Model & Deviance & Residual df \\
\hline Null & 2973.2 & 26 \\
Colony & 1038.0 & 23 \\
Distance & 1041.1 & 25 \\
\hline
\end{tabular}


should be of the same magnitude. Indeed, the variance of the resightings exceeds the mean in all colonies except at the Chafarinas Islands (there was only 1 observation from the Chafarinas Islands) while variance and mean are supposed to be equal for a Poisson distribution (Table 4).

To account for overdispersion, we decided to use the negative binomial distribution instead of the Poisson distribution (Crawley 1993, p. 347). The aggregation parameter $k$ of the negative binomial distribution can be estimated by solving a nonlinear equation. We solved this equation for each colony separately by means of a macro provided by Crawley (1993, p. 339) (see Table 4) For the colony of Chafarinas Islands, as already mentioned, there was only 1 observation at the Ebro Delta (Table 2), so the procedure does not apply. For the other colonies, the amount of overdispersion is comparable. We decided to use a value of $k$ common to all colonies from the range of estimated $k$ values. Different values were tried leading to very similar results; we give the results for $k=2 / 3$ (Table 5). The colony and the distance models fit well this time. Qualitatively, the results are much the same as with the Poisson models. The colony effect accounts for $67 \%$ of the total deviance, of which distance explains $97 \%$. The effect of distance is very significant $\left(\chi_{1}^{2}=46.20, p<0.0001\right)$. The effect of colony in presence of the effect of distance is not significant $\left(\chi_{2}^{2}=1.38, p=0.50\right)$. The fitted values for the best model, the distance model, leads to the equation:

$$
\begin{aligned}
\log \left[\mathrm{E}\left(R_{c, \mathrm{~h}}\right)\right]= & \mathrm{A}_{c, \mathrm{~h}}-0.9372(\mathrm{SE} \mathrm{0.3606)-} \\
& 0.01112(\mathrm{SE} 0.002066) \cdot \mathrm{km}
\end{aligned}
$$

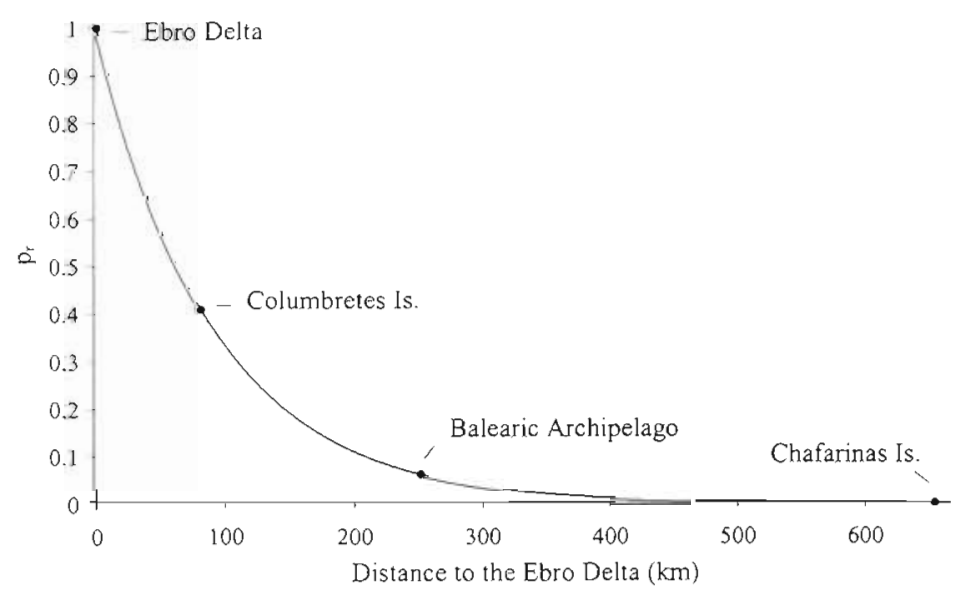

Fig. 2. Probability of breeding at the Ebro Delta depending on the colony of origin and the distance following the equation $\log (j r)=$ $0.9372-0.01112 \cdot \mathrm{km}$ (from the best model $\log \left[\mathrm{E}\left(R_{\mathrm{c}, \mathrm{h}}\right)\right]=A_{\mathrm{c}, \mathrm{h}}-0.9372$ (SE 0.3606)-0.01112 (SE 0.002066) $\cdot \mathrm{km}$ ); since $j$ is unknown, we cannot estimate the probability of breeding directly, only the probability relative to the Ebro Delta colony, called $\mathrm{p}_{\mathrm{r}}$. For the Balearic Archipelago, we took the average distance from several colonies of the Archipelago
Table 4. Variance and mean of the resightings of breeders at the Ebro Delta colony by colony of origin. The maximurn likelihood estimate of the parameter $k$ of the negative binomial distribution for these data sets is also shown, except for the Chafarinas ls. colony since only 1 bird from the Chafarinas Is. was observed at the Ebro Delta (na: not available)

\begin{tabular}{|lccc|}
\hline Colony & Variance & Mean & $k$ \\
\hline Ebro Delta & 37453.48 & 177.86 & 0.85 \\
Columbretes Is. & 14.48 & 2.86 & 0.70 \\
Balearic Arch. & 88 & 6 & 0.44 \\
Chafarinas Is. & 0.14 & 0.14 & na \\
\hline
\end{tabular}

Very few studies on the movements among populations of long-lived birds have been carried out due to the difficulty of marking individuals in different local populations within a metapopulation (e.g. Hestbeck et al. 1991, Aebischer 1995, Spendelow et al. 1995). These studies show that birds tend to show a high fidelity to the breeding or wintering grounds, with low probabilities of moving from the site used previously (see also Porter 1988). Spendelow et al. (1995) found that distance between colony sites was not an important factor in movement probabilities of breeding roseate terns Sterna dougallii, although it may be that the distance between colonies was not sufficiently large relative to the movement abilities of this species. However, recruitment in kittiwakes Rissa tridactyla was found to decrease with the distance from the natal colony (Coulson \& Nève de Mévergnies 1992). Similarly, the recruitment pattern of Audouin's gulls within the western Mediterranean metapopulation clearly depends on distance, with low recruitment rate to the Ebro Delta from the other colonies, especially from the most distant ones (Fig. 2). Among seabirds, the few studies performed at the metapopulation level suggest that dispersal distance is probably species-specific, related to the foraging habits of the species. Adult movement rates for pelagic or semipelagic species of seabirds such as kittiwakes and Audouin's gulls (Coulson \& Nève de Mévergnies 1992, our study) are probably of lesser magnitude than those of more coastal

Table 5. Negative binomial models with the extra parameter $k=2 / 3$ (see text)

\begin{tabular}{|lcc|}
\hline Model & Deviance & df \\
\hline Null & 70.741 & 26 \\
Colony & 23.165 & 23 \\
Distance & 24.542 & 25 \\
\hline
\end{tabular}


species like large gulls, shags or terns (Coulson 1991, Aebischer 1995. Spendelow et al. 1995 respectively). Thus, results from pelagic seabird species would agree better with the prediction of some theoretical models that individual transfer rate (e.g. dispersal, recruitment) should increase when distance between local populations decreases within a metapopulation (e.g. Brown \& Kodric-Brown 1977, Hansson 1991). However, environmental factors must also play an important role in determining dispersal distance. Since breeding habitat heterogeneity is very high for Audouin's gull within the metapopulation, some colonies may attract more individuals than others depending on their habitat quality, food availability or density of predators (Oro et al. 1996b, Oro \& Pradel in press). It would be of great interest to carry out the same type of analysis for recruitment on the other colonies. Previous results from studies on the migration of Audouin's gulls born in the Ebro Delta showed that gulls may move large distances of more than $3500 \mathrm{~km}$ after the breeding season, not only to the southern wintering grounds in Africa but also to the eastern parts of the Mediterranean (Oro \& Martínez-Vilalta 1994, Oro 1998). Unfortunately, at the moment, observations of breeding adults outside the Ebro Delta are too scarce to permit such an analysis to be performed. However, recent intense surveys at Italian and Greek colonies looking for birds ringed at the Spanish colonies suggest that transfer to these colonies, if it exists, is very low (Nicola Baccetti \& Hellenic Ornithological Society pers. obs.). In addition, nothing is known about recruitment from other colonies outside the study area since ringing has not been carried out; only the Algerian colonies are within the maximum distance considered in our study, whereas colonies in Corsica, Sardinia, the Tuscany Archipelago, Tunisia and the most distant colonies in Greece, Cyprus and Turkey are further away (Oro 1998). Recruitment may vary not only through space, but also with time: at the Ebro Delta, local recruitment of Audouin's gulls has increased together with time, since the increase of colony size has attracted more recruits (Oro \& Pradel in press, see also Kharitonov \& Siegel-Causey 1988, Brown et al. 1990). Thus, recruitment to the Ebro Delta at the metapopulation level has probably increased with time.

Although recruitment to the Ebro Delta from the other colonies was low, it could be of great importance for the gene flow among colonies (at a genetic level) and for the dynamics of that colony (at a demographic level). At a population genetic level, it is known than only 1 or 2 migrants per generation will cause 2 otherwise isolated populations to behave as if mating between them is panmictic (Hoelzel \& Dover 1991). Our results confirm recent analyses of genetic structure of this metapopulation, which indeed show that there is a gene flow among colonies even between the most distant colonies of the Ebro Delta and Chafarinas Islands (Genovart unpubl. results). Recent simulation models of multiple populations have shown that a very small number of immigrants per year allow local populations to persist even in stochastic environments where they would otherwise become extinct (e.g. Fahrig \& Merriam 1985, Beier 1993). Since its establishment in 1981, the colony has grown at an average rate of $45 \%$; it is clear that this growth can only be explained by a high immigration rate, probably natal dispersal from other colonies. The colony has probably been a strong population sink, not only during the first years but also in recent years (Oro \& Ruxton unpubl. results). Suitable environmental conditions at the Ebro Delta in terms of availability of both food and nest sites probably attracted recruits to this colony, a mechanism that has been enhanced in recent years by the conspecific attraction of such a large colony (Oro et al. 1996b, Oro \& Pradel in press). The origin (single or multiple) of the individuals who were initially established there is unknown, but results suggest that in 1997 only dispersal from the neighbouring colony of the Columbretes Island colony was large (Fig. 2). In fact, previous studies have shown a strong demographic relationship between the 2 colonies (Oro et al. 1999, Oro \& Pradel in press). However, only the colony of Chafarinas Islands held a large number of Audouin's gulls during the 1980s, and several authors suggested that the birds colonizing the Ebro Delta were probably recruited from this site (de Juana \& Varela 1993).

To conclude, the present study shows that distance between colonies is an important factor in the transfer of individuals within a metapopulation of Audouin's gulls in the western Mediterranean. Although the movement abilities of the species are very high during the breeding and non-breeding seasons, the probability of a move to the Ebro Delta from one of the other colonies of the metapopulation decreases exponentially with the distance. Although at a very low rate, dispersal was recorded even from the most distant colony at the Chafarinas Islands, $655 \mathrm{~km}$ from the Ebro Delta.

Acknowledgements. We are extremely grateful to Meritxell Genovart for helping with the field work; to all the people involved in the ringing programme over the years and at all the colonies, especially to Albert Martinez-Vilalta, Juan Jiménez, Jordi Muntaner and Georgina Alvarez; to Bob Furness and 3 anonymous referees for critical reading of the manuscript; to Jean-Dominique Lebreton for his methodological advice; to Xavier Ruiz and Lluis Jover for their support; and to Charo Cañas for providing data on the Audouin's gull ringing programme. The Audouin's gull ringing programme was conceived by the Plan Coordinado para la Protección de la gaviota de A.udouin chaired by the ICONA. Research funds were provided by the DGICYT grant PB91-0271, P. N. del Delta de l'Ebre, Servei de Protecció i Gestió de la Fauna (Generalitat dé 
Catalunya), P. N. Illes Columbretes (Generalitat Valenciana), Govern Balear and ICONA. D.O. was supported by grants of the CIRIT (Generalitat de Catalunya) and the European Science Foundation (Program in Population Biology).

\section{LITERATURE CITED}

Aebischer NJ (1995) Philopatry and colony fidelity of Shags Phalacrocorax aristotelis on the east coast of Britain. Ibis $137: 11-18$

Aitkin M, Anderson D, Francis B. Hinde J (1988) Statistical modelling in GLIM. Clarendon. Oxford

Arcos JM, Oro D (1996) Changes in foraging range of Audouin's Gull Larus audouinii in relation to a trawler moratorium in the western Mediterranean. Colon Waterbirds 19:128-131

Beier P (1993) Determining minimum habitat areas and habitat corridors for cougars. Conserv Biol 7:94-108

Brown JH, Kodric-Brown A (1977) Turnover rates in insular biogeography: effect of immigration on extinction. Ecology $58: 445-449$

Brown CR, Stutchbury BJ, Walsh PD (1990) Choice of colony size in birds. Trends Ecol Evol 5:398-403

Clobert J, Julliard R, McCleery RH (1993) The components of local recruitment. In: Lebreton JD, North PM (eds) Marked individuals in the study of bird population. Birkhäuser Verlag, Basel, p 281-293

Cooke F, Francis CM (1993) Challenges in the analysis of recruitment and spatial organization of populations. In: Lebreton JD, North PM (eds) Marked individuals in the study of bird population. Birkhäuser Verlag. Basel, p 295-308

Coulson JC (1991) The population dynamics of culling Herring Gulls and Lesser Black-backed Gulls. In: Perrins CM, Lebreton JD, Hirons GJM (eds) Bird population studies, relevance to conservation and management. Oxford University Press, Oxford, p 479-497

Coulson JC, Nève de Mévergnies G (1992) Where do young kittiwakes Rissa tridactyla breed, philopatry or dispersal? Ardea 80:187-197

Crawley MJ (1993) GLIM for ecologists. Blackwell Science, Oxford

De Juana E, Varela J (1993) La población mundial reproductora de la gaviota de Audouin (Larus audouinii). In: Aguilar JS, Monbailliu X, Paterson AM (eds) Status and conservation of seabirds. SEO, Madrid p 71-85

del Hoyo J, Elliott A, Sargatal J (1996) Handbook of the birds of the world, Vol 3. Lynx Ediciones, Barcelona

Fahrig L, Merriam G (1985) Habitat patch connectivity and population survival. Ecology 66:1762-1768

Hanski I, Gilpin ME (1997) Metapopulation biology: ecology, genetics and evolution. Academic Press, London

Hansson L (1991) Dispersal and connectivity in metapopulations. Biol J Linnean Soc 42:89-103

Hestbeck JB, Nichols JD. Malecki RA (1991) Estimates of movement and site fidelity using mark-resight data of wintering Canada Geese. Ecology 72:523-533

Hoelzel AR, Dover GA (1991) Molecular genetic ecology. Oxford University Press, Oxford

Editorial responsibility: Otto Kinne (Editor),

Oldendort/Luhe, Germany
Ims RA, Yoccoz NG (1997) Studying transfer processes in metapopulations: emigration, migration and colonization. In: Hanski I, Gilpin ME (eds) Metapopulation biology: ecology, genetics and evolution. Academic Press, London, p 247-266

Johnson ML, Gaines MS (1990) Evolution of dispersal: theoretical models and empiricals tests using birds and mammals. Annu Rev Ecol Syst 21:449-480

Jiménez J, Carda J (1997) Invernada de la gaviota de Audouin Larus audouinit en las islas Columbretes. Ardeola 44:183-189

Kharitonov SP, Siegel-Causey D (1988) Colony formation in seabirds. In: Johnson RF (ed) Current ornithology. Plenum Press, New York, p 223-272

Lambertini M (1996) International action plan for Audouin's Gull (Larus audouinii). In: Heredia B, Rose L, Painter M (eds) Globally threatened birds in Europe. Council of Europe Publishing, Strasbourg, p 289-302

MacArthur RH, Wilson EO (1967) The theory of island biogeography. Princeton University Press, Princeton

Mace GM, Collar NJ (1994) Extinction risk assessment for birds through quantitative criteria. Ibis 137:240-246

Oro D (1998) Audouin's gull account. In: Ogilvie MA (ed) The Birds of Western Paleartic. Oxford University Press, Oxford (in press)

Oro D, Martínez-Vilalta A (1994) Migration and dispersal of Audouin's Gull Larus audouinii from the Ebro Delta. Ostrich 65:225-230

Oro D, Pradel R (in press) Determinants of local recruitment in a growing colony of Audouin's gull. J Anim Ecol

Oro D, Genovart X, Ruiz X, Jiménez J, García-Gans J (1996b) Differences in diet, population increase and breeding performance between two colonies of Audouin's Gulls Larus audouinii during breeding seasons affected by a trawling moratorium. J Avi Biol 27:245-251

Oro D, Jover L, Ruiz X (1996a) Influence of trawling activity on the breeding ecology of a threatened seabird, Audouin's Gull Larus audouinii. Mar Ecol Prog Ser 139: $19-29$

Oro D, Pradel R, Lebreton JD (1999) Food availability and nest predation influence life history traits in Audouin's gull Larus audouinii. Oecologia 118:438-445

Porter JM (1988) Prerequisites for recruitment of Kittiwakes Rissa tridactyla. Ibis 130:204-215

Pradel R (1996) Animal dispersal within subdivided populations: an approach based on monitoring individuals. Acta CEcol 17:475-483

Pradel R, Johnson AR, Viallefont A, Nager RG, Cézilly F (1997) Testing biological hypotheses about recruitment using capture-mark-recapture data: a case study in the Greater Flamingo. Ecology 78:1431-1445

Smith AT, Peacock MM (1990) Conspecific attraction and the determination of metapopulation colonization rates. Conserv Biol 4:320-323

Spendelow JA, Nichols JD, Nisbet ICT, Hays H, Cormons GD, Burger J, Safina C. Hines JE, Gochfeld M (1995) Estimating annual survival and movement rates of adult within a metapopulation of Roseate Terns. Ecology 76 : $2415-2428$

Submitted: September 11, 1998; Accepted: November 18, 1998 Proofs received from author(s): April 6, 1999 